\title{
TINGKAT PENGEMBALIAN INVESTASI PADA CV. INDUSTRI CAHAYA BARU
}

\author{
Khaerul Iman \\ Jurusan Manajemen Fakultas Ekonomi Dan Bisnis Universitas Teknologi Sumbawa
}

\begin{abstract}
Abstrak
Berdasarkan perhitungan Net Profit Margin, CV. Industri Cahaya Baru mampu menghasilkan penjualan dalam menghasilkan laba bersih yaitu 19\% pada tahun 2015, tingkat laba terus meningkat ditahun 2016 sebesar $43 \%$ ini berarti setiap Rp. 1 penjualan menghasilkan laba bersih sebesar Rp. 0,43, kemudian pada tahun 2017 laba yang dihasilkan mengalami penurunan menjadi 31\%. Berdasarkan perhitungan Total Asset Turnover, tingkat kemampuan perputaran aktiva CV. Industri Cahaya Baru terhadap penjualan ditahun 2015 sebesar $73 \%$ kemudian pada tahun 2016 sebesar 77\% dan pada tahun 2017 mengalami penurunan 33\%.Berdasarkan perhitungan Return on Investment (ROI), tingkat ROI yang dihasilkan perusahaan pada tahun 2015 sebesar $14 \%$ dan ditahun 2016 perusahaan mampu meningkatkan ROI nya menjadi 77\% dan tahun 2017 perusahaan ROI yang dihasilkan perusahaan menurun menjadi 33\%. Berdasarkan perhitungan Economic Value Added (EVA) pada tahun 2015 belum bisa memberikan nilai tambah untuk perusahaan sedangkan ditahun 2016 dan 2017 CV. Industri Cahaya Baru memiliki nilai tambah ekonomi yang negatif.
\end{abstract}

Kata kunci : CV. Industri Cahaya Baru, Du pont, Econmic Value Added (EVA)

\section{Pendahuluan}

Setiap perusahaan memiliki beberapa tujuan diantaranya adalah untuk meningkatkan penjualan, memaksimalkan kinerja operasional perusahaan dan mendapat laba optimal. Tercapainya atau tidaknya laba optimal dapat diketahui dalam laporan keuangan perusahaan. Hasil analisis laporan keuangan dapat mencerminkan kondisi kinerja keuangan perusahaan, oleh karena itu informasi - informasi di dalam laporan keuangan harus memuat tentang pencatatan keuangan secara sistematis tentang posisi keuangan (Kasmir, 2012). Penilaian kinerja keuangan suatu perusahaan sangat penting dilaksanakan untuk menilai kondisi keuangan suatu perusahaan. Dengan kinerja keuangan yang baik sebuah perusahaan dapat bertahan dan berkembang, begitu pula sebaliknya bila kinerja keuangan tidak baik maka akan menyebabkan kerugian yang besar bagi perusahaan. Menurut Martono dan Hartijo (2003) dalam usaha pencapaian tujuan perusahaan, khususnya pencapaian laba maksimal ditetapkan melalui strategi perusahaan dan penilaian kinerja dengan melakukan analisis keuangan perusahaan.

Salah satu yang sering digunakan untuk mengukur kinerja perusahaan khususnya pusat pertanggung jawaban investasi adalah Return On Investment (ROI) dan Economic Value Added (EVA). Menurut Topowijono (2015) Perusahaan memiliki Return On Investment (ROI) yang tinggi dianggap menghasilkan kinerja yang baik dan sebaliknya. Namun pihak investor dalam menilai perusahaan, tentunya tidak hanya melihat pengembalian (return) yang dihasilkan, tetapi juga biaya modal yang dikeluarkan oleh perusahaan. Dengan menggunakan metode Economic Value Added (EVA), perusahaan akan memfokuskan perhatiannya pada penciptaan nilai tambah perusahaan. Karena menyertakan unsur biaya modal dalam perhitungannya, pendekatan ini tidak hanya mengukur tingkat pengembalian yang dihasilkan perusahaan tapi juga secara langsung mempertimbangkan risiko yang dihadapi perusahaan. 
Du Pont system merupakan suatu pendekatan mengukur tingkat efektifitas perusahaan dalam menghasilkan keuntungan. Sistem ini memberikan gambaran elemen - elemen yang saling berhubungan dan berpengaruh pada tingkat pengembalian investasi suatu perusahaan, Return On Investment (ROI) yaitu margin laba bersih, perputaran total aktiva dan tingkat hutang suatu perusahaan. Rangkuti (2009:136). "Dengan mengetahui dan memahami elemen - elemen tersebut, dapat membantu manajemen dalam memutuskan kebijakannya dalam rangka untuk meningkatkan tingkat pengembalian atas investasi terlihat dimana letak elemeneleme Return On Investmen (ROI) yang sangat berpengaruh". Du Pont dapat memberikan informasi mengenai berbagai faktor yang menyebabkan perubahan tingkat kinerja keuangan suatu perusahaan.

Return On Investment (ROI) merupakan salah satu indikator yang sering digunakan untuk menghitung tingkat keberhasilan manajemen perusahaan dalam melakukan tingkat pengembalian investasi. Return On Investment (ROI) akan menunjukan seberapa banyak laba bersih yang dapat diperoleh dari seluruh kekayaan yang dimiliki perusahaan (Raharjo, 2009). Return On Investment (ROI) Merupakan rasio yang menunjukan kemampuan perusahaan dengan seluruh investasi yang ada didalamnya untuk menghasilkan keuntungan. Jadi dapat disimpulkan bahwa Return On Investment (ROI) merupakan pengukuran kemampuan perusahaan secara keseluruhan didalam menghasilkan keuntungan dengan jumlah investasi yang telah dilakukan perusahaan. Secara umum semakin besar rasio Return on Investment semakin baik karena berarti semakin besar kemampuanperusahaandalammenghasilkan laba. Penggunaan konsep Return on investment sebagai alat mengukur kinerja keuangan perusahaan sudah banyak diterapkan sebagian besar perusahaan saat ini. Namun penggunaan Return on Investment sebagai alat ukur terhadap laba perusahaan yang memiliki beberapa kelemahan yaitu tidak memperhatikan risiko yang dihadapi perusahaan dengan mengabaikan biaya modal dan hanya memperhatikan hasilnya (laba perusahaan) sehingga sulit untuk mengetahui apakah perusahaan tersebut telah berhasil menciptakan nilai perusahaan atau tidak.
Selain $D u$ Pont ada metode lain yang dapat digunakan untuk menganalisis kinerja keuangan yaitu analisis Economic Value Added (EVA). Metode analisis Economic Value Added (EVA) mengukur kinerja keuangan yang menggabungkan memperoleh nilai dengan biaya untuk memperoleh nilai tambah tersebut (Mamdu, 2004). Kemudian perlu ditambahkan bahwa kelebihan konsep Economic Value Added (EVA) adalah bermanfaat sebagai penilaian kinerja yang berfokus pada penciptaan nilai tambah bagi perusahaan, membuat perusahaan untuk memperhatikan biaya modal dan dapat digunakan untuk mengidentifikasikan kegiatan perusahaan yang memberikan pengembalian tinggi dari biaya modal.Economic Value Added (EVA) merupakan salah satu cara untuk menilai kinerja keuangan yang dihitung dengan cara mengurangkan Net Operating Profit After Tax dengan Weighted Averange Cost Of Cafital dikali dengan Invested Capital. Metode EVA diharapkan dapat memperoleh hasil perhitungan nilai ekonomis perusahaan yang realistis, dan juga dapat mendukung penyajian laporan keuangan sehingga dapat mempermudah para pemakai laporan keuangan dalam melakukan analisis terhadap kinerja keuangan perusahaan dalam rangka pembuatan keputusan untuk investasi.

\section{Rumusan Masalah :}

a. Bagaimana tingkat pengembalian investasidari $\mathrm{CV}$. Industri Cahaya Baru dilihat dari Return on Investment?

b. Bagaimana tingkat pengembalian investasi $\mathrm{CV}$. Industri Cahaya Baru dilihat dari Economic Value Added?

\section{Tujuan Penelitian :}

a. Untuk mengetahui tingkat pengembalian investasi dilihat dari Return on Investmen.

b. Untuk mengetahui tingkat pengembalian investasi dilihat dari Economic Value Added.

\section{Studi Literatur :}

a. Investasi adalah kegiatan menanamkan modal untuk di nikmati di masa mendatang dengan harapan jumlah investasi yang ditanamkan sekarang bisa bertambah nilainya seiring waktu 
yang telah desepakati bersama. Beberapa macam aset yang digunakan untuk berinvestasi adalah aset real dan aset financial. Calon investor akan membeli aset financial karena aset ini gampang diperjual belikan untuk kebutuhan mendadak (Hanafi, 2004:144).

b. Pengertian laba secara operasional merupakan perbedaan antara pendapatan yang direalisasi yang timbul dari transaksi selama satu periode dengan biaya yang berkaitan dengan pendapatan tersebut. Pengertian laba menurut kelebihan penghasilan di atas biaya selama satu periode akuntansi. Sementara pengertian laba yang dianut oleh struktur akuntansi sekarang ini adalah selisih pengukuran pendapatan dan biaya. Besar kecilnya laba sebagai pengukur kenaikan sangat bergantung pada ketepatan pengukuran pendapatan dan biaya (Subramanyam, 2014). Laba merupakan angka yang penting dalam laporan keuangan karena berbagai alasan antara lain, laba merupakan dasar dalam perhitungan pajak, pedoman dalam menentukan kebijakan investasi dan pengambilan keputusan, dasar dalam peramalan laba maupun kejadian ekonomi perusahaan lainnya di masa yang akan datang, dasar dalam perhitungan dan penilaian efisiensi dalam menjalankan perusahaan, serta sebagai dasar dalam penilaian prestasi atau kinerja perusahaan.

c. Laporan Keuangan adalah hasil dari proses akutansi yang dapat digunakan sebagai alat berkomunikasi antara data keuangan atau aktivitas suatu perusahaan dengan pihak-pihak yang berkepentingan dengan data atau aktivitas perusahaa (Munawir, 2002).

d. Analisis $D u$ Pont adalah suatu sistem analis yang dimaksudkan untuk menunjukan hubungan antara return on investmen, net Profit margin dan total asset turnover. Analisis tersebut mencakup rasio aktivitas dan profitabilitas atas penjualan untuk menunjukan bagaimana rasio-rasio ini saling mempengaruhi, analisis ini menunjukan pengembalian atas aktiva (Topowijono, 2015). Analisis $D u$ Pont penting untuk melakukan pengawasan keuangan terhadap perusahaan dan terutama divisi yang ditetapkan sebagai profit center. Analisis Du Pont juga dapat dikatakan sebagai return on investment (ROI) yang didefinisikan laba setelah pajak dibagi total aktiva. Sedangkan persamaan $D u$ Pont adalah rumus yang menunjukan bahwa tingkat pengembalian atas aktiva dapat diperoleh dengan mengalihkan margin laba bersih dengan perputaran total aktiva (Brigham dan Houston, 2001).

- $\quad$ Net Profit Margin merupakan perbandingan antara laba bersih usaha dengan penjualan. Net Profit Margin adalah rasio yang digunakan untuk menunjukan kemampuan perusahaan dalam menghasilkan keuntungan bersih. Semakin besar NPM, maka kinerja perusahaan akan semakin produktif, sehingga akan meningkatkan kepercayaan investor untuk menanamkan modalnya pada perusahaan tersebut. Rasio ini menunjukkan berapa besar persentase laba bersih yang diperoleh dari setiap penjualan. Semakin besar rasio ini, maka dianggap semakin baik kemampuan perusahaan untuk mendapatkan laba yang tinggi. Hubungan antara laba bersih dan penjualan bersih menunjukkan kemampuan manajemen dalam menjalankan perusahaan secara cukup berhasil untuk menyisakan margin tertentu sebagai kompensasi yang wajar bagi pemilik yang telah menyediakan modalnya untuk suatu risiko.

Net Profit Margin dituliskan dengan rumus (Brigham dan Houston, 2001)

$$
N P M=\frac{\text { Laba Bersih }}{\text { Penjualan }} \times 100
$$

Perhitungan Net Profit Margin dimaksudkan untuk mengetahui efisiensi perusahaan dengan mengetahui besar kecilnya laba usaha dalam hubungannya dengan tingkat penjualan. Besar kecilnya Net Profit Margin pada setiap transaksi penjualan dipengaruhi oleh dua faktor, yaitu penjualan bersih dan laba usaha. Dengan jumlah biaya usaha tertentu, Net Profit Margin dapat diperbesar dengan memperbesar penjualan. Dengan jumlah penjualan tertentu, Net Profit Margin dapat diperbesar dengan memperkecil jumlah biaya usaha.Alternatif sebagai usaha untuk memperbesar Net Profit Margin, yaitu (Riyanto, 2001). Dengan menambah biaya usaha sampai tingkat tertentu diusahakan tercapainya tambahan penjualan yang sebesar-besarnya, atau dengan kata lain 
tambahan penjualan harus lebih besar dari pada tambahan biaya usaha.

- Total Asset Turnover yaitu kecepatan perputaran aktiva usaha dalam suatu periode tertentu. Total Asset Turnover dapat ditentukan dengan membagi penjualan dengan aktiva usaha. Dengan demikian,

Total Asset Turnover dimaksudkan untuk mengetahui efisiensi perusahaan dengan melihat pada kecepatan perputaran aktiva digunakan untuk mengukur efisiensi penggunan aktiva untuk menghasilkan penjualan.

Rumus Total Asset Turnover adalah (Brigham dan Houston, 2001)

$$
\text { TATO }=\frac{\text { Penjualan }}{\text { Total Aktiva }} \times 1 \text { kali }
$$

Tinggi rendahnya tingkat Total Asset Turnover dipengaruhi oleh faktor penjualan besih dan aktiva usaha. Penggunaan sejumlah aktiva usaha tertentu, menambah besarnya jumlah penjualan selama periode tertentu, dengan semakin kecil aktiva usaha menjadi semakin tinggi Toal Asset Turnover.

- $\quad$ Analisis ROI dalam analisis keuangan memiliki arti yang sangat penting sebagai salah satu teknik analisis keuangan yang bersifat menyeluruh. Return on investment sendiri adalah salah satu bentuk dari rasio frofitabilitas yang dimaksudkan untuk dapat mengukur kemampuan perusahaan dengan keseluruhan dana yang ditanamkan dalam aktiva yang digunakan untuk operasi perusahaan untuk menghasilkan keuntungan. Dengan kata lain, return on investment yaitu ukuran untuk menunjukan efisiensi penggunaan modal dalam suatu perusahaan. Return on investment adalah kempuan suatu perusahaan untuk menghasilkan laba (Riyanto, 2001).

Menurut Riyanto (2001) Return on investment adalah rasio keuntungan neto sesudah pajak dengan jumlah total aktiva usaha sehingga dalam analisis $D u$ Pont diperhitungkan juga bunga dan pajak. ROI merupakan pengukuran kemampuan perusahaan secara keseluruhan didalam menghasilkan keuntungan barsih sesudah pajak.
Besarnya ROI dapat diketahui dengan rumus :

$$
\text { ROI = Net Profit Margin } \times \text { Total Asset Turnover }
$$

e. Economic Value Added (EVA) adalah nilai tambah kepada pemegang saham oleh manajemen dalam suatu periode tertentu. EVA merupakan suatu estimasi laba ekonomis yang sesungguhnya dari perusahaan dalam tahun berjalan. EVAmenunjukan sisi laba setelah biaya modal ekuitas, termasuk modal ekuitas, dikurangkan sedangkan laba akutansi ditentukan tanpa memperhitungkan modal ekuitas (Brigham dan Houston, 2001).

Dalam hal investasi, EVA mampu mendorong manajer berpikir untuk memilih investasi yang memaksimumkan pengembalian dengan biaya modal yang minimum sehingga nilai perusahaan bisa ditingkatkan. Selain itu, faktor biaya modal yang terdapat dalam EVA mendorong manajer untuk berhati-hati dalam menentukan kebijakan struktur modal perusahaannya. Dengan perhitungan EVA diharapkan dapat memperoleh hasil perhitungan pada upaya penciptaan nilai perusahaan yang lebih realistis ( Pinangkaan, 2012).

- Langkah - Langkah Menghitung Economic Value Added (EVA)

a. Menghitung NOPAT

Menurut wahyudiono (2014), Net Operating After Tax menunjukan laba yang akan diperoleh perusahaan apabila perusahaan tidak menggunakan hutang dan atau tidak memiliki non-operating assest. Net Operating After Tax dapat dihitung dengan rumus sebagai berikut :

$$
\begin{aligned}
& \text { NOPAT }=\text { EBIT } \times(1-\text { Tax }) \\
& \text { NOPAT }=\text { Net Operating Profit After Tax } \\
& \text { EBIT }=\text { Earning Before Interest and Tax }
\end{aligned}
$$

Tax $=$ Pajak penghasilan perusahaan

$$
\begin{aligned}
& \text { b. Menghitung modal rata - rata tertimbang } \\
& \text { Setelah membahas komponen modal secara } \\
& \text { individu baru menghitung biaya modal secara } \\
& \text { keseluruhan yaitu menghitung Weighted Average Cost } \\
& \text { of Capital }(\mathrm{WACC}) \text {. } \\
& \mathrm{WACC}=(\mathrm{We} . \mathrm{Ke})+\left(\mathrm{Wd} . \mathrm{Kd}^{*}\right) \\
& \mathrm{WACC}=\text { biaya modal rata }- \text { rata tertimbang } \\
& \mathrm{We}=\text { bobot ekuitas }
\end{aligned}
$$




$$
\begin{aligned}
\mathrm{Ke} & =\text { biaya modal sendiri } \\
\mathrm{Wd} & =\text { bobot hutang } \\
\mathrm{Kd}^{*} & =\text { biaya hutang setelah pajak }
\end{aligned}
$$

c. Analisis Economic Value Added (EVA)

Economic Value Added (EVA) merupakan estimasi laba ekonomi usaha yang sebenarnya untuk tahun tertentu. EVA dapat dirumuskan sebagai berikut :

$\mathrm{EVA}=\mathrm{NOPAT}-(\mathrm{WACC} \times \mathrm{IC})$

\section{Metode Penelitian}

Penelitian ini menggunakan jenis penelitian deskriptif dengan melakukan pendekatan kuantitatif. Peneliti berupaya mendiskripsikan dan memberikan gambaran mendetail mengenai kinerja keuangan perusahaan dengan perhitunganDuPont System dan Economic Value Added yang keduanya akan dipaparkan berupa angka-angka yang kemudian dijelaskan dalam suatu uraian (Sugiyono, 2009). Sumber data dalam penelitian ini adalah berasal dari laporan keuangan perusahaan periode 2015 - 2017.

Populasi dalam penelitian ini adalah laporan keuangan CV. Industri Cahaya Baru dari tahun 2011 2017. Yang dilakukan dengan teknik purposive sampling dengan kriteria :

a. Data yang diambil tiga tahun terakhir yaitu dari tahun

2015 - 2017 karena trend terjadi selama tiga tahun belakang.

b. Data yang diambil sudah diaudit oleh perusahaan.

Tahapan - tahapan analisis data yang dilakukan dalam analisis ini adalah :

1. Analisis kinerja keuangan dengan Du Pount System

a. Perhitungan Total Asset Turnover (TATO)

Total asset Turnover $=\frac{\text { Penjualan }}{\text { Total Aktiva }} \times 1$ kali

b. Perhitungan Net Profit Margin (NPM)

Net Profit Margin $=\frac{\text { Laba Bersi } h}{\text { Penjualan }} \times 100$

c. Perhitungan Return on Investment (ROI)

Return on Investmen $=$ TATO $\mathrm{x}$ NPM

2. Analisis perhitungan Economic Value Added (EVA)
a. Menghitung Net Operating Profit After Tax (NOPAT)
NOPAT $=$ EBIT $\times(1-$ Tax $)$
NOPAT $=$ Laba Bersih Setelah Pajak
EBIT = Penghasilan sebelum bunga dan pajak
Tax $=$ Pajak Penghasilan Perusahaan

b. Menghitung Weighted Averange Cost of Cavital (WACC)

$\mathrm{WACC}=(\mathrm{We} \cdot \mathrm{Ke})+\left(\mathrm{Wd} \cdot \mathrm{Kd}^{*}\right)$

- Proporsi Ekuitas (We)

$\mathrm{We}=\frac{\text { Total Ekuitas }}{\text { Total Hutang }+ \text { Total Ekuitas }} \times 100$

- Proporsi Hutang (Wd)

$\mathrm{Wd}=\frac{\text { Total Hutang }}{\text { Total Hutang }+ \text { Total Ekuitas }} \times 100$

- Biaya Hutang sebelum pajak (Kd)

$$
\mathrm{Kd}=\frac{\text { Biaya Bunga }}{\text { Total Hutang }} \times 100
$$

- Biaya Hutang setelah pajak $\left(\mathrm{Kd}^{*}\right)$

$$
\mathrm{Kd}^{*}=\mathrm{Kd}(1-\mathrm{T})
$$

- Biaya Ekuitas (Ke)

$$
\mathrm{Ke}=\frac{\text { Laba Bersi h Setela h Pajak }}{\text { Total Modal }} \times 100
$$

c. Menghitung Tingkat Pajak

$$
\mathrm{T}=\frac{\text { Beban Pajak }}{\text { Laba Sebelum Pajak }} \times 100
$$

d. Menghitung Invested Cavital

Invested Cavital $=$ Total Asset - Hutang jangka pendek

e. Menghitung Economic Value Added (EVA)

$$
\mathrm{EVA}=\mathrm{NOPAT}-(\mathrm{WACC} \times \mathrm{IC})
$$

\begin{tabular}{|c|c|c|c|c|}
\hline TAHUN & PENJUALAN & $\begin{array}{c}\text { TOTAL } \\
\text { AKTIVA }\end{array}$ & TATO & \\
\hline 2015 & $\begin{array}{l}\text { Rp. } \\
2.147 .000 .000\end{array}$ & $\begin{array}{l}\text { Rp. } \\
2.940 .648 .000\end{array}$ & 0,73 kali & \\
\hline 2016 & $\begin{array}{l}\text { Rp. } \\
5.782 .310 .000\end{array}$ & $\begin{array}{l}\text { Rp. } \\
3.253 .548 .000\end{array}$ & 1,78 kali & $143 \%$ \\
\hline 2017 & $\begin{array}{l}\text { Rp. } \\
3.986 .802 .500\end{array}$ & $\begin{array}{l}\text { Rp. } \\
3.651 .398 .000\end{array}$ & 1,09 kali & $(39 \%)$ \\
\hline
\end{tabular}

\section{Hasil dan Pembahasan}

\section{Analisis Kinerja Keuangan Dengan Du Pont System}

\section{a. Perhitungan Total Asset Turnover (TATO)}

Tabel Error! No text of specified style in document..1. Perhitungan Total Asset Turnover

CV. Industri Cahaya Baru tahun 2015-2017

Sumber : data sekunder diolah

Pada tahun 2015 perusahaan dapat menghasilkan penjualan sebesar 0,73 kali, yang artinya bahwa setiap 1 total aktiva yang dimiliki perusahaan akan menghasilkan 0,73 kali penjualan. Kemudian pada tahun selanjutnya yaitu tahun 2016, perputaran aktiva CV. Industri Cahaya Baru tahun 2016 sebesar 1,78 kali penjualan. Dari 
perputaran aktiva pada tahun 2016 terjadi peningkatan sebesar $143 \%$ atau menjadi 1,78 kali penjualan apabila dibandingkan dengan tahun 2015. Hal ini menunjukan bahwa pada tahun 2016 perusahaan mampu memaksimalkan total aktiva yang dimilikinya. Selanjutnya perputaran aktiva pada tahun 2017 perusahaan mampu menghasilkan penjualan sebesar 1,09 kali dari 1 total aktiva yang dimilikinya. Akan tetapi pada tahun 2017 perusahaan mengalami penurunan dilihat dari perubahan TATO sebesar 39\% bila dibandingkan dengan tahun 2017 hal ini menunjukan bahwa pada tahun 2017 perusahaan tidak seefektif tahun 2016 dalam penggunaan aktiva yang ada.

\section{b. Perhitungan Net Profit Margin (NPM)}

Tabel Error! No text of specified style in document..2 Perhitungan Net Profit Margin CV. Industri Cahaya Baru tahun 2015-2017

\begin{tabular}{|c|c|c|c|c|}
\hline TAHUN & $\begin{array}{c}\text { LABA } \\
\text { BERSIH }\end{array}$ & PENJUALAN & NPM & $\begin{array}{c}\text { PERU } \\
\text { BAH } \\
\text { AN } \\
\text { NPM }\end{array}$ \\
\hline 2015 & $\begin{array}{l}\text { Rp. } \\
406.252 .240\end{array}$ & $\begin{array}{l}\text { Rp. } \\
2.147 .000 .000\end{array}$ & $19 \%$ & \\
\hline 2016 & $\begin{array}{l}\text { Rp. } \\
2.513 .581 .1 \\
40\end{array}$ & $\begin{array}{l}\text { Rp. } \\
5.782 .310 .000 \\
\end{array}$ & $43 \%$ & $25 \%$ \\
\hline 2017 & $\begin{array}{l}\text { Rp. } \\
1.222 .046 .7 \\
15 \\
\end{array}$ & $\begin{array}{l}\text { Rp. } \\
3.986 .802 .500 \\
\end{array}$ & $31 \%$ & $(13 \%)$ \\
\hline
\end{tabular}

Sumber : data sekunder diolah

Dari tabel net profit margin diatas dapat diketahui bahwa pada tahun 2015 perusahaan dapat menghasilkan laba bersih sebesar $19 \%$ atau dapat diartikan juga bahwa dalam setiap Rp. 1 penjualan menghasilkan laba bersih sebesar Rp. 0,19 sedangkan yang Rp. 0,81 habis untuk menutupi biaya - biaya operasi perusahaan. kemudian pada tahun 2016 net profit margin $\mathrm{CV}$. Industri Cahaya Baru meningkat sebesar $25 \%$ atau menjadi $43 \%$ hal ini terjadi karena meningkatnya juga penjualan pada tahun 2016 jika dibandingkan dengan tahun 2015. Lalu pada tahun selanjutnya yaitu tahun 2017 , net profit margin CV. Industri Cahaya Baru mengalami penurunan sebesar $13 \%$ atau menjadi $31 \%$ hal ini terjadi karena menurunnya penjualan pada tahun 2017 .

\section{Perhitungan Return on Investmen (ROI)}

Tabel Error! No text of specified style in document..3 Daftar Perhitungan Return on Investment, (ROI) CV. Industri Cahaya Baru tahun 2015-2017

\begin{tabular}{|l|l|l|l|}
\hline \multirow{2}{*}{ Keterangan } & \multicolumn{3}{|c|}{ Tahun } \\
\cline { 2 - 4 } & 2015 & 2016 & \multicolumn{1}{|c|}{2017} \\
\hline NPM $\%$ & $19 \%$ & $43 \%$ & $31 \%$ \\
\hline TATO $\%$ & $73 \%$ & $178 \%$ & $109 \%$ \\
\hline ROI \% & $14 \%$ & $77 \%$ & $33 \%$ \\
\hline Perubahan ROI & & $63 \%$ & $(44 \%)$ \\
\hline
\end{tabular}

Sumber : data sekunder diolah

Dari tabel 4.3 diatas terlihat perkembangan Return On Investment $\mathrm{CV}$. Industri Cahaya Baru pada tahun 2015 ROI yang dihasilkan oleh perusahaan sebesar 14\% atau kata lain pada tahun 2015 tingkat pengembalian investasi yang diberikan oleh perusahaan sebesar 14\% dan pada tahun 2016 CV. Industri Cahaya Baru mampu meningkatkan ROI sebesar $63 \%$ menjadi $77 \%$ hal ini menunjukan bahwa terjadi peningkatan terhadap tingkat pengembalian dalam menghasilkan laba yang diberikan oleh CV. Industri Cahaya Baru sangat efektif apabila dibandingkan dengan ROI tahun 2015. Hal ini juga diakibatkan meningkatnya juga penjualan yang dilakukan oleh CV. Industri Cahaya Baru karena pada tahun 2016 perusahaan mendapatkan tender proyek dikabupaten sumbawa sehingga pada tahun 2016 tinggkat pengembalian yang diberikan oleh perusahaan sangat besar bila dibandingkan dengan tahun 2015. Kemudian pada tahun 2017 ROI Menurun sebesar 44\% atau menjadi 33\%. Perbedaan selisih ini diakibatkan karena pada tahun 2017 perusahaan mengalami penurunan penjualan dibandingkan dengan tahun 2016.

\section{Menghitung Metode Economic Value Added (EVA)}

A. Menghitung Pajak

Tabel Error! No text of specified style in document..4.

Perhitungan Pajak CV. IndustriCahaya BaruTahun 20152017

\begin{tabular}{|r|c|c|r|}
\hline TAHUN & $\begin{array}{c}\text { BEBAN } \\
\text { PAJAK }\end{array}$ & $\begin{array}{c}\text { LABA SEBELUM } \\
\text { PAJAK }\end{array}$ & PAJAK \\
\hline 2015 & $\mathrm{Rp} 21.470 .000$ & $\mathrm{Rp} 427.722 .240$ & $5 \%$ \\
\hline 2016 & $\mathrm{Rp} 57.823 .100$ & $\mathrm{Rp} 2.571 .404 .240$ & $2 \%$ \\
\hline 2017 & $\mathrm{Rp} 39.868 .025$ & $\mathrm{Rp} 1.261 .914 .740$ & $3 \%$ \\
\hline
\end{tabular}

Sumber : data sekunder diolah

Pada tahun 2015 CV. Industri Cahaya Baru dengan pajak yang dibebankan terhadap perusahaan sebesar 5\% dengan kata lain pajak yang dibebankan oleh perusahaan 
sebesar Rp. 21.470 .000 dan pada tahun 2016 sebesar 2\% dengan beban pajak sebesar Rp. 57.823.100 kemudian 3\% untuk tahun 2017 dengan beban pajak sebesar Rp. 39.868.025. Berubahya tarif pajak karenaasumsihnyapenelitidenganmenggunakanrumusdiat as, karenapenelititidakmengetahuijumlahpajak yang sebenarnyadariperusahaan. Dengan mengetahui jumlah pajak yang dibebankan ke perusahaan sehingga dapat menghitung langkah-langkah selanjutnya.

\section{b. Menghitung Net Operating After Tax (NOPAT)}

Tabel Error! No text of specified style in document..5. Perhitungan NOPAT CV. IndustriCahaya BaruTahun2015-2017

\begin{tabular}{|c|c|c|c|}
\hline TAHUN & EBIT & $\begin{array}{c}(1- \\
\text { TAX })\end{array}$ & NOPAT \\
\hline 2015 & Rp. 540.500 .000 & $95 \%$ & Rp. 513.475.000 \\
\hline 2016 & Rp. 2.721 .830 .000 & $98 \%$ & Rp. 2.667.393.400 \\
\hline 2017 & Rp.1.460.082.500 & $97 \%$ & Rp. 1.416 .280 .025 \\
\hline
\end{tabular}

Sumber : data sekunder diolah

Berdasarkan tabel 4.5 diatas pada tahun 2015 laba bersih sebelum pajak sebesar Rp. 540.500.000, dengan pajak yang dibebankan ke perusahaan sebesar 5\% perusahaan mampu menghasilkan laba bersih setelah pajak sebesar Rp. 513.475.000. Kemudian pada tahun 2016 perusahaan mampu menghasilkan laba bersih setelah pajak sebesar Rp. 2.667.393.400 dengan beban jumlah pajak yang dibebankan ke perusahaan sebesar 2\% dengan laba bersih sebelum pajak sebesar Rp. 2.721.830.000. Pada tahun 2017 laba bersih sebelum pajak sebesar Rp. 1.460.082.500, dengan pajak yang dibebankan ke perusahaan sebesar 3\% perusahaan mampu menghasilkan laba bersih setelah pajak sebesar Rp. 1.416.280.052.

\section{Menghitung WACC}

Tabel Error! No text of specified style in document..6.

Perhitungan WACC CV.Industri Cahaya BaruTahun 2015-2017

\begin{tabular}{|r|r|r|r|r|r|}
\hline \multicolumn{1}{|c|}{ TAHUN } & $\mathrm{We} \%$ & $\mathrm{Ke} \%$ & $\mathrm{Wd} \%$ & $\mathrm{Kd} \% \%$ & WACC $\%$ \\
\hline 2015 & $68 \%$ & $26 \%$ & $32 \%$ & $11 \%$ & $21 \%$ \\
\hline 2016 & $61 \%$ & $133 \%$ & $39 \%$ & $12 \%$ & $86 \%$ \\
\hline 2017 & $55 \%$ & $71 \%$ & $45 \%$ & $12 \%$ & $44 \%$ \\
\hline
\end{tabular}

Sumber : data sekunder diolah
WACC menggambarkan biaya rata-rata yang harus dikeluarkan perusahaan untuk mendapatkan total modal, yang berasal dari hutang + ekuitas adalah sebesar Pada tahun 2015 WACC sebesar $21 \%$ dapat diartikan bahwa penggunaan hutang dan ekuitas dalam menjalankan kegiatan usaha sebesar $21 \%$ dari hutang dan ekuitas yang ada, sehingga pengembalian yang diharapkan oleh investor untuk kembali atas investasi pada tahun 2015 yaitu sebesar diatas $21 \%$.

\section{Menghitung Invested Cavital}

\section{Tabel Error! No text of specified style in} document..7. Perhitungan IC

\begin{tabular}{|r|l|c|l|}
\hline & TOTAL & $\begin{array}{r}\text { HUTANG } \\
\text { JANGKA }\end{array}$ & \\
TAHUN & ASET & PENDEK & IC \\
\hline 2015 & Rp & & Rp \\
\hline & 2.940 .648 .000 & $\mathrm{Rp} 390.648 .000$ & 2.550 .000 .000 \\
\hline 2016 & 3.253 .548 .000 & $\mathrm{Rp} 803.548 .000$ & $\mathrm{Rp}$ \\
\hline & $\mathrm{Rp}$ & & $\mathrm{Rp}$ \\
2017 & 3.651 .398 .000 & $\mathrm{Rp} 1.101 .398 .000$ & 2.550 .000 .000 \\
\hline
\end{tabular}

Sumber : data sekunder diolah

Berdasarkan tabel diatas investasi berupa pinjaman pada tahun 2015 sebesar Rp. 2.550.000.000 yang digunakan sebagai modal untuk membiayai kegiatan operasi perusahaan. Padatahun 2016 investasiberupapinjamansebesarRp. 2.450.000.000 yang digunakansebagai modal untukmembiayaikegiatanoperasiperusahaandanpadatahun 2017 investasiberupapinjamansebesarRp. 2.550.000.000.

\section{E. Menghitung Economic Value Added (EVA)}

Tabel Error! No text of specified style in document..8. Perhitungan EVA CV. Industri Cahaya Baru 2015-2017

\begin{tabular}{|c|l|l|l|}
\hline TAHUN & NOPAT & (WACC x IC ) & EVA \\
\hline & Rp. & Rp. & Rp. \\
2015 & 513.463 .974 & 540.600 .000 & $(27.125 .000)$ \\
\hline & Rp. & Rp. & Rp. \\
2016 & 2.660 .624 .280 & 2.102 .345 .000 & 565.048 .400 \\
\hline & Rp. & Rp. & Rp. \\
2017 & 1.413 .953 .706 & 1.133 .475 .000 & 282.805 .025 \\
\hline
\end{tabular}

Sumber : data sekunder diolah

Economi Value Added (EVA) menggambarkan kemampuan perusahaan dalam menghasilkan nilai tambah kepada pemilik perusahaan. Berdasarkan tabel 4.13 CV. Industri Cahaya Baru diatas dapat diketahui kemampuan perusahaan dalam menghasilkan nilai tambah kepada pemilik perusahaan. Pada tahun 2015 $\mathrm{CV}$. Industri Cahaya Baru menghasilkan nilai EVA 
negatif sebesar Rp. 27.125.000, yang berarti CV. Industri Cahaya Baru tidak dapat menutupi semua kewajiban kepada pemilik. Hal ini dikarenakan nilai laba bersih setelah pajak (NOPAT) sebesar Rp. 513.475.00 tidak mampu menutup biaya modal yang diinvestasikan sebesar Rp. 2.550.000.000. Yang artinya pada tahun 2015 perusahaan belum bisa memberikan nilai tambah kepada pemilik.

Kemudian pada tahun 2016 nilai EVA yang dihasilkan oleh perusahaan bernilai positif sebesar Rp. 565.048.400 hal ini mampu memberikan nilai tambah kepada pemilik karena diakibatkan laba bersih yang dihasilkan perusahaan setelah pajak mampu menutupi kewajiban kepada pemilik. Selanjutnya pada tahun 2017 perusahaan kembali mampu memberikan nilai tambah ke pemilik dengan menghasilkan nilai EVA sebesar Rp. 282.805 .025 .

\section{Kesimpulan dan Saran}

1. Berdasarkan data yang diperoleh dapat diketahui bagaimana tingkat pengembalian investasi pada $\mathrm{CV}$. Industri Cahaya Baru dengan metode analisis Return on Investment (ROI) dan metode analisis Economic Value Added (EVA) setiap tahunnya selama tiga tahun berturut-turut yaitu tahun 2015, 2016 dan 2017, maka dapat ditarik kesimpulan sebagai berikut :

a. Dengan Metode Return on Investment (ROI)

Pada tahun 2015 dari total keseluruhan investasi perusahaan mampu memberikan tingkat pengembalian sebesar 14\%, pada tahun 2016 tingkat pengembalian sebesar $77 \%$ dan pada tahun 2017 tingkat pengembalian sebesar 33\% hal ini menunjukan bahwa tingkat pengembalian yang diberikan oleh perusahaan setiap tahunnya berubah - rubah. Dari CV. Industri Cahaya Baru tingkat pengembalian paling bagus diberikan pada tahun 2016.

b. Dengan Metode Economic Value Added (EVA)

Pada tahun 2015 ROI perusahaan menunjukan keuntungan akan tetapi setelah melakukan perhitungan biaya modal dengan menggunakan metode Economic Value Added (EVA) ternyata pada tahun 2015 EVA yang dihasilkan perusahaan bernilai negatif sebesar Rp. 27.152.000 ini menunjukan bahwa perusahaan belum bisa menutupi keseluruhan biaya investasinya dengan kata lain perusahaan belum bisa memberikan nilai tambah untuk perusahaan, kemudian pada tahun selanjutnya yaitu tahun 2016 perusahaan mampu memberikan nilai tambah sebesar Rp. 565.048.400 dan mampu menutupi keseluruhan investasi yang dilakukan oleh pemilik. Pada tahun 2017 perusahaan mampu memberikan nilai tambah bagi perusahaan. Nilaitambah yang

dimaksuddisiniadalahmeningkatnyalabaoperasitanpaadan yatambahan modal berartimanajemendapatmenggunakanaktivaperusahaanse carabaikuntukmendapatkankeuntungan yang optimal. Selainitu, denganberinvestasikeproyek - proyek yang menerimatingkatpengembalianlebihbesardaripadabiaya modal yang digunakan, berartimanajemenperusahaanhanyamengambilproyek yang bermutudanmeningkatkannilaiperusahaan.

Dari pernyataan diatas bahwa pada tahun 2016 perusahaan sangat efektif memberikan pengembalian investasi dan memberikan nilai tambah bagi pemilik bila dibandingkan dengan tahun 2015 dan 2017.

\section{Saran}

Menggunakan metode penilaian atas tingkat pengembalian yang lebih banyak, karena dengan begitu keadaan tingkat pengembalian perusahaan akan lebih terlihat dengan jelas.

\section{Daftar Pustaka}

Kasmir. 2012. Analisis Laporan Keuangan . Jakarta: PT Raja Grafindo Persada.

Martono, Hartijo. 2003. Manajemen Keuangan. Yogyakarta: Liberti.

Topowijono. 2015. Analisis Du pont system sebagai salah satu alat mengukur kinerja keuangan perusahaan. Jurnal Administrasi Bisnis (JAB) Vol.23 No.1 1-9.

Rangkuti, Freddy. 2009. Strategi Promosi yang Kreatif dan Analisis Kasus Integrated Marketing. Jakarta: Gramedia Pustaka Utama.

Raharjo, Budi. 2009. Laporan Keungan Perusahaan. Yogyakarta: Gadjah Mada University Press. 
Hanafi, Mamdu. 2004. Manajemen keuangan edisi ke satu. Yogyakarta: BPFE.

Subramanyam. 2014. Analisis laporan keuangan edisi 11. Jakarta: Selemba empat.

Munawir. 2002. Analisis Laporan Keuangan. Yogyakarta: Liberty.

Brigham dan Houston. 2001. Manajemen Keuangan II. Jakarta: Salemba empat.

Raharjo, Budi. 2009. Laporan Keungan Perusahaan. Yogyakarta: Gadjah Mada University Press.

Pinangkaan, Getereida. 2012. Pengaruh Return On Investmen (ROI) dan Economic Value Added (EVA) terhadap return saham perusahaan. Forum Bisnis dan Kewirausahaan ilmiah STIE MDP 99-111.

Wahyudiono. 2014. Mudah Membaca Laporan Keuangan. Yogyakarta: Raih Asa Sukses.

Sugiyono. 2009. Metodelogi Penelitian kuantitatif, kualitatif. Bandung: Alfabeta. 